\title{
Challenges in Engaging Birdwatchers in Bird Monitoring in a Forest Patch: Lessons for Future Citizen Science Projects in Agricultural Landscapes
}

\author{
Eduardo Roberto Alexandrino*, Ana Beatriz Navarro*, Valdir Felipe Paulete', Maristela \\ Camolesi"*, Vosmarline Graziela Rocha Limat, Austin Green§, Tiago de Conto", Katia \\ Maria Paschoaletto Micchi de Barros Ferraz*, Çağan Hakkı Şekercioğlu§,n and Hilton \\ Thadeu Zarate do Coutoll
}

\begin{abstract}
Birdwatchers hold substantial potential as data collectors for research, and in Brazil, the birdwatching community has been growing since the early 2000s. Currently the effects of birds on forest patch restoration in agricultural landscapes is a major focus of avian conservation ecology, but these patches are not frequently visited by birdwatchers in Brazil, hindering the collection of useful bird data. We thus developed a project, Did I see a banded bird!? which was designed to attract birdwatching volunteers to monitor birds within a forest patch. We explored three motivating factors to attract birdwatchers: (1) we offered an unprecedented opportunity for birdwatchers to record individual birds with colored bands, a challenging activity appealing to birdwatchers' competitive nature; (2) our study area offered a new location with free, easy access and no logistical impediments; and (3) we continuously provided information on the benefits of birdwatching records for science and society to encourage participation. The project was widely announced and we had 302 applicants. However, the barriers faced throughout the project's execution, including limited researcher-volunteer interaction, low security in the patch, and the presence of few species for birdwatchers to see, reduced the motivation and participation of most applicants. Consequently, from a list of 155 highly qualified applicants who lived near the patch and were skilled in forest birding, only 10 visited the patch. Our findings provide important guidelines for researchers planning similar citizen science projects in agricultural landscapes, mainly in countries where citizen science is still not common.
\end{abstract}

Keywords: avian ecology; participatory science; birdwatching; bird banding; bird resighting; forest restoration; ornithology; serious leisure; tropical biology; ecotourism

\section{Introduction}

A key component of citizen science is the involvement of volunteers to collect data for academic research and scientific projects to support environmental management (Chandler et al. 2017; Pettibone et al. 2016; Callaghan et al. 2018). In the last few decades, several ecology and nature conservation studies have been undertaken based on extensive citizen science databases of fauna and flora collected worldwide

\footnotetext{
* Universidade de São Paulo - USP, Escola Superior de Agricultura "Luiz de Queiroz" - ESALQ, Laboratório de Ecologia, Manejo e Conservação de Fauna Silvestre - LEMaC, Av. Pádua Dias, Piracicaba, SP, BR

Universidade Metodista de Piracicaba - UNIMEP. Rodovia do açúcar, Km 156 - Taquaral, Piracicaba, SP, BR

- Universidade Federal de São Carlos - UFSCar, campus Sorocaba. Rod. João Leme dos Santos, Km, Sorocaba, SP, BR

University of Utah, Department of Biology, Biodiversity and
}

(Abolafya et al. 2013; Chandler et al. 2017; McKinley et al. 2017).

Bird records at local, regional, and global scales are the most common faunal data provided by citizen scientists (Sullivan et al. 2014, 2017). In countries where birdwatching has a long history and strong community ties, various ecological projects are based on these data (e.g., Scott et al. 1999; Cordell and Herbert 2002; Chandler et al. 2017; Sullivan et al. 2017), which are becoming

\footnotetext{
Conservation Ecology Lab, 257 South 1400 East, Salt Lake City, UT, US

" Universidade de São Paulo - USP, Escola Superior de Agricultura "Luiz de Queiroz" - ESALQ, Laboratório de Métodos Quantitativos - LMQ, Av. Pádua Dias, Piracicaba, SP, BR

" Koç University, College of Sciences, Rumelifeneri, Sariyer 34450, Istanbul, TR

Corresponding author: Eduardo Roberto Alexandrino (eduardoalexandrino@hotmail.com)
} 
increasingly valuable for monitoring the health of bird populations (Horns et al. 2018). As more citizens become birdwatchers and collect reliable bird records, the quality of the data collected may begin to rival that of data collected by professionals (Szabo et al. 2012; Callaghan et al. 2018), who are far fewer in number and are underfunded, especially in the tropics (Şekercioğlu 2012; Horns et al. 2018).

In Brazil, birdwatching started to become popular only in the past decade, when annual bird fairs for birdwatchers started and new technologies for observing, photographing, and identifying birds became financially accessible to the wider public (Pivatto and Sabino 2007; Alexandrino et al. 2018). Because of this popularization, many Brazilian birdwatchers freely share bird records (e.g., observations, checklists, photos, and bird song recordings) on global online citizen science platforms such as eBird (Sullivan et al. 2014, 2017) and iNaturalist (www.inaturalist.org) as well as on national platforms like WikiAves and Taxeus (Klemann-Junior et al. 2017, Alexandrino et al. 2018; Taxeus 2018; WikiAves 2018). In addition, these platforms have further contributed to the rising number of new Brazilian birdwatchers, a pattern that has been observed in other countries after the launch of online citizen science platforms for bird records (Chu et al. 2012; Sullivan et al. 2014, 2017).

There are no official statistics about the current numbers of Brazilian birdwatchers; the current number of WikiAves users provides the best, but conservative, estimate. In 11 August 2018, WikiAves had 29,504 users. Most of them reside in southeastern Brazil (Figure 1). In this region, large remnants of natural ecosystems, such as national and state parks protecting native Atlantic Forest (Ribeiro et al. 2009), have been the main target of many birdwatchers due to high bird diversity in these areas (Hasui et al. 2018). In contrast, forest patches in agricultural landscapes have attracted relatively few birdwatchers, even though ecologists are continuously seeking bird data from forest patches in agricultural landscapes to improve knowledge for sustainable management in these areas (Majer 2009; Verdade et al. 2014; Rezende et al. 2015; Boesing et al. 2017; Alexandrino et al. 2018).

In agricultural landscapes, characterized by the presence of crops for food and raw material production, anthropogenic interventions are frequent (Verdade et al. 2016). This is the case for most of the original extent of the Brazilian Atlantic Forest biome, where $80 \%$ of current remnants are confined to small patches in agricultural landscapes (Dean 1997; Ribeiro et al. 2009). These patches have a variety of shapes, sizes, and isolation levels. Most are secondary forest (Ferraz et al. 2014) exposed to a variety of anthropogenic impacts, including fire (Martinelli and Filoso 2008), cattle trampling (Pereira et al. 2015), illegal logging, and hunting (Aleixo 1999; Cullen Jr. et al. 2001). This habitat fragmentation and anthropogenic disturbance has been reported as the main driver of Atlantic Forest defaunation and biodiversity loss, which, consequently, may compromise the ecosystem services that these areas provide (Banks-Leite et al. 2014; Bello et al. 2015; Bovo et al. 2018; Brancalion et al. 2018). Because of this, claims for forest restoration in agricultural landscapes have increased in recent years (Rodrigues et al.

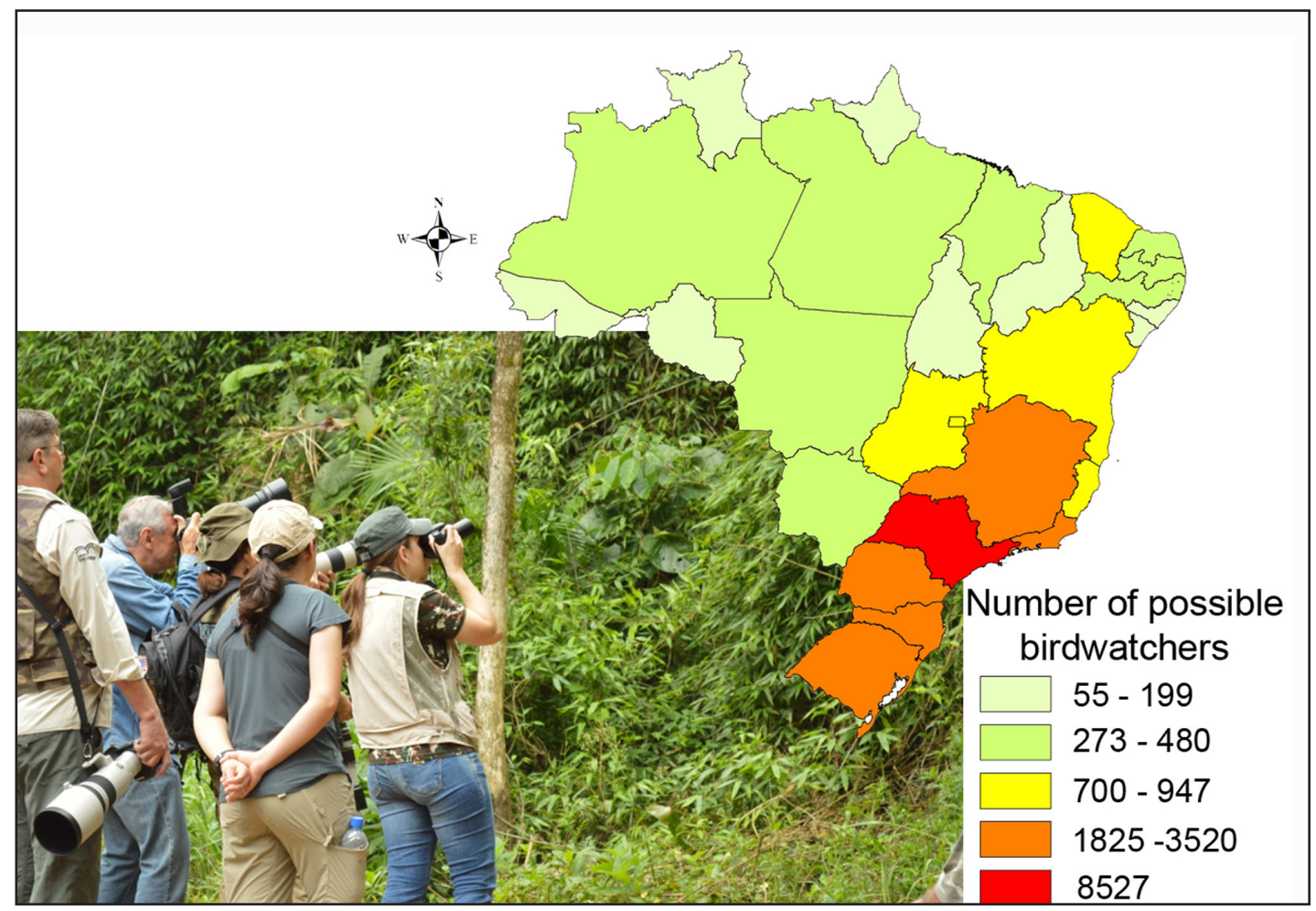

Figure 1: Number of possible birdwatchers in Brazil represented by WikiAves users (WikiAves 2018). WikiAves is the most popular website for bird record sharing used by Brazilian birdwatchers. The figure highlights distribution of WikiAves users by Brazilian states (data from 11 August 2018). Photo: Eduardo R. Alexandrino. 
2009; Banks-Leite et al. 2014). However, the cost of active restoration by people is usually extremely high and unfeasible in degraded areas with low resilience, such as in some agricultural landscapes in southeastern Brazil (Rodrigues et al. 2009; Brancalion et al. 2012; Tambosi et al. 2014).

In contrast, birds may assist in passive forest restoration (Ferraz et al. 2014; Rezende et al. 2015), without the need for human intervention (Pizo 2007; Whelan et al. 2008; Peña-Domene et al. 2013). Even in agricultural landscapes with functionally deficient bird communities (e.g., Dias et al. 2016; Alexandrino et al. 2017; Bovo et al. 2018), many frugivorous birds are still common and it is difficult to infer which, if any, species may act as promoters of forest restoration through fruit and seed dispersal over adjacent areas (Pizo 2007; Şekercioğlu et al. 2016; Pizo and Santos 2011; Silveira et al. 2016). Therefore, understanding the movement patterns of these relatively lower-diversity bird communities in small forest patches, together with information on their ecological traits and plant interactions, would improve our knowledge of passive forest restoration promoted by birds. Although there are various methods to follow birds in forested habitats, including miniaturized GPS tags (e.g., Hallworth and Marra 2015), radio tracking (e.g., Şekercioğlu et al. 2007; Silveira et al. 2016), or by doing long-term research using mist net captures and recaptures (e.g., Marini 2010), the long-term costs can be very high. Especially in countries facing financial crises and budget cuts for science (e.g., in Brazil, see Angelo 2017; Overbeck 2018), alternative methods are urgently needed. A promising alternative is large-scale and high-resolution bird monitoring by citizen scientists (Cohn 2008; Tulloch and Szabo 2012; Horns et al. 2018).

After more than 10 years since the beginning of birdwatching popularization in Brazil, we wanted to find out whether the current Brazilian birdwatching community could support a citizen science research project focusing on surveying forest patches in an agricultural landscape, in order to assess the role that birds play in passive forest restoration. We tested the feasibility of a citizen science project based on birdwatching volunteers identifying and monitoring individual birds within forest patches. As the feasibility of ecological research based on citizen scientist data is still poorly investigated in Brazil, our goals included understanding the motivations of citizen scientists and providing guidelines for researchers planning similar citizen science projects. Herein, we describe: (1) the stages of our project and our strategy to engage volunteers, (2) the bird data provided by the volunteers and their utility to the project, (3) the motivations and barriers that influenced the willingness of applicants to collect the requested data in the field, and (4) the feasibility of our project outline.

\section{Methods \\ Study area}

Our project was carried out in the Corumbataí River Basin in the interior of the São Paulo state, southeastern Brazil (22 $\left.04^{\prime} 46^{\prime \prime} / 22^{\circ} 41^{\prime} 28^{\prime \prime} \mathrm{S}-47^{\circ} 26^{\prime} 23^{\prime \prime} / 47^{\circ} 56^{\prime} 15^{\prime \prime} \mathrm{W}\right)$, approximately $180 \mathrm{~km}$ from São Paulo, the biggest city in Brazil (Figure 2a). The river basin is $1710 \mathrm{~km}^{2}$ in area and is composed of small to medium size cities (i.e., 15,000-200,000 inhabitants; IBGE 2018) and agricultural mosaics, where cattle pastures and sugarcane form the majority of the agricultural matrix. Small amounts of semi-deciduous seasonal forest (Atlantic Forest biome) and savannah woodland (Cerrado biome) are confined to the native forest remnants found in the agricultural landscape (i.e., approximately $12 \%$ of the river basin, see Valente and Vettorazzi 2003). In the last few years, six focal landscapes covering $16 \mathrm{~km}^{2}$ and representative of the river basin agricultural landscape in terms of land use composition (>70\% agricultural matrix - sugarcane or cattle pasture - and $>10 \%$ native forest) have been the focus of research on land use change, forest restoration, ecology, and ornithology (Cassiano et al. 2013; Ferraz et al. 2014; Alexandrino et al. 2016, 2017; César et al. 2018) (Figure 2b). Many forest patches in the region have increased their area by passive restoration (Ferraz et al. 2014; Alexandrino et al. 2016). Our citizen science-based project was originally planned to be performed in three riparian forest patches located in private rural properties across three different focal landscapes (Figure $\mathbf{2 b}$ ). In the past, we conducted bird point counts in these patches (see Ferraz et al. 2012; Alexandrino et al. 2016, 2017), and in 2016 we started bird capture-recapture research using mist nets, as part of our continued research in the area. However, the present project involved non-research personnel visiting the patches, and the landowners of two patches located on small family properties at the north river basin (in Corumbataí and Rio Claro municipalities, see location of patches A and B in Figure $\mathbf{2 b}$ ) were reluctant to allow access to volunteers, citing security concerns and a fear of disturbance (e.g., there were cases of robbery and illegal hunting in that region). Therefore, our citizen science project was carried out in only one of these three patches located at Santa Olímpia in the south river basin (i.e., patch $C$ in Figure $\mathbf{2 b}$ ), a rural village $19 \mathrm{~km}$ from Piracicaba, the biggest city in the region. This patch was within a rural property leased by the sugarcane processing company Raízen, which is responsible for the patch. An employee of the company permitted us to proceed with the project.

The Santa Olímpia patch is 38 ha and was composed mostly of a Eucalyptus plantation until 2000, when the stopping of logging resulted in passive forest restoration (Ferraz et al. 2014). Because of this previous usage, the patch is bordered by a dirt road, which allows access by car until the edge of the patch. Furthermore, the patch also contains three transects that run through the interior of the forest and provide access for low speed motocross and hiking (Figure 2c).

\section{Banding birds in the forest patch}

In the patch core area, we established four bird banding stations, with at least $200 \mathrm{~m}$ distance between each other (Figure 2c). Each station was composed of five mist-nets (32 mm mesh, $12 \mathrm{~m}$ length, and $2.8 \mathrm{~m}$ height) operated for a maximum of five continuous hours per field day, starting 30 minutes after sunrise. We conducted 


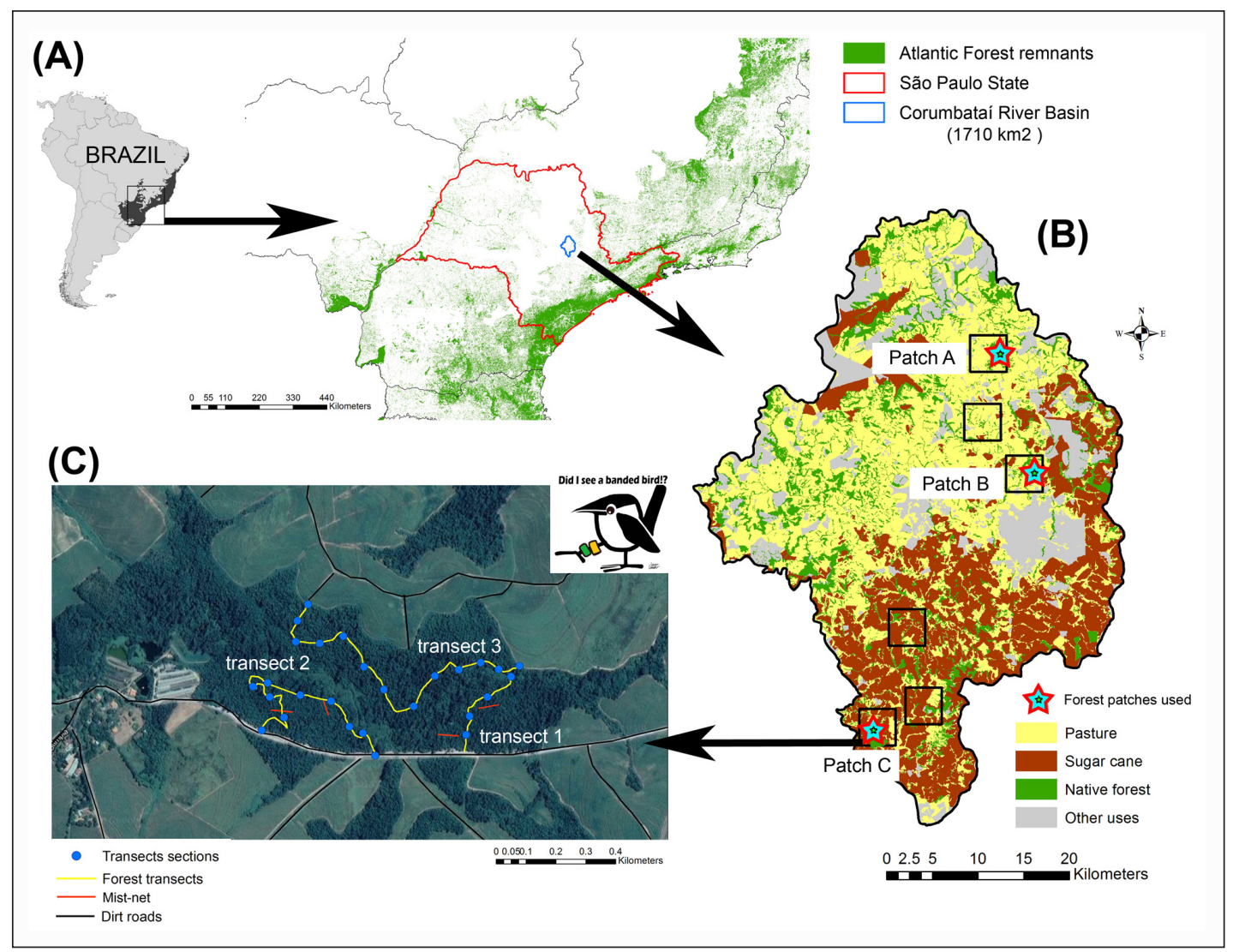

Figure 2: A) Location of the Corumbataí River Basin in southeastern Brazil in São Paulo state. Only a few remnants of the original cover of the Atlantic forest biome (dark grey in 2a) are left after years of human impact. B) Now, Corumbataí River basin is predominantly an agricultural landscape. Black squares are focal landscapes used by research since 2011, composed of $70 \%$ of matrix and $10 \%$ of native forest. Three forest patches were originally targeted for this project, but only patch "C" was used. C) The Santa Olímpia forest patch, where our project "Did I see a banded bird?" was carried out. The forest patch lies within a sugarcane matrix. Birdwatching transects (yellow) were subdivided into sections (blue points) of 150 meters. Red lines represent mist netting stations for bird banding. Satellite image from Google Earth. Project logo was created by Luccas Longo, reproduced here with his permission.

279 mist-net/hours (we consider one mist-net/hour as one $12 \mathrm{~m}$ long net opened for $1 \mathrm{~h}$ ) during 15 days of banding between September 2016 and August 2017.

Each bird captured was identified to species and received a numbered metallic band provided by the Centre for Bird Monitoring of the Brazilian Institute for Environmental Affairs (CEMAVE/IBAMA) and up to three color plastic bands in a unique color combination regardless of the species, in order to allow individual identification via visual observation (Marini 2010). Before releasing the bird, we also took photographs and biometric measurements such as bill length, height and width, and body mass.

\section{Strategy to recruit volunteers and assessing their willingness to help}

Our project was designed with the assumption that small forest patches in agricultural landscape would not be as attractive to Brazilian birdwatchers as large forest patches, based on birdwatching records from 2006 until present showing a distinct preference by birdwatchers to visit large protected natural reserves and ecosystem remnants (see Pivatto and Sabino 2007; Pivatto et al. 2007; Alexandrino et al. 2018). In addition, our forest patch has relatively lower species richness, as well as few records of threatened and endemic species, when compared with the natural reserves most popular among Brazilian birdwatchers (Hasui et al. 2018; Bovo et al. 2018), who often specifically look for certain species (e.g., Pivatto et al. 2007). Nevertheless, because Brazil's São Paulo state hosts the highest number of resident birdwatchers (Alexandrino et al. 2018, Figure 1), we assumed that we could attract these birdwatchers if we offered a unique activity that went beyond species checklists, increasing their "life list" or seeing target species (e.g., Tulloch and Szabo 2012, see Scott et al. 1999; Alexandrino et al. 2012). Thus, we decided to create a citizen science project based on friendly competition (e.g., Scott et al. 1999; Sullivan et al. 2014; Frigerio et al. 2018). Searching for banded birds in forest patches was an unprecedented activity for birdwatchers in Brazil until 2016, and we used this advantage to attract candidate volunteers for our project.

By April 2017, we had reached 224 mist-net-hours, banded 80 individuals, and started recording banded birds in the field (e.g., Bovo 2016; Paulete 2016). In light of this, we began to announce our project to capture the attention of potential citizen scientists. We used several 
means of communication to increase our chances of reaching a greater proportion of the birdwatching community (Chu et al. 2012; Frigerio et al. 2018), including creating a popular name ("Did I see a banded bird!?") and an intuitive project logo (Figure 2c). We used Facebook, WikiAves, and Taxeus as our main channels to publicize the project to our target audience. Our project was also broadcast across Internet news sites (e.g., Birding News 2017; Eler 2018) and was registered in SciStarter.com and in the official webpage of the Brazilian Ministry of Science, Technology, Innovation and Communication (Sibbr 2018), where many other national citizen science projects are publicized. Our project was also covered in a regional TV program watched by birdwatchers (i.e., Terra da Gente at Globo, the most popular Brazilian TV channel, see G1 2017). We also gave presentations about the project in the popular Brazilian Bird Fair AVISTAR São Paulo and two other regional fairs in southeastern Brazil. Between April 2017 and January 2018, we posted 37 Facebook posts about our project in the timeline of Eduardo Alexandrino (best public engagement throughout the project was 987 visualizations on one post with 22 sharing and 100 likes); on the Facebook page of the Wildlife Ecology, Management, and Conservation Lab (maximum of 624 people reached); and in groups that deal with subjects such as nature, birding, ecotourism, science, ornithology, environmental science, and photography. Our posts had the project's logo, pictures, and short videos of some banded birds (https://youtu.be/HFz4FNTE64Q) followed by a short text explaining the project and the link to access the online application form. Between July 1, 2017 and February 27, 2018, each WikiAves user resident in the São Paulo State and all users of Taxeus (i.e., 8293 and 2500 users, respectively) received an email about the project and an invitation to join. The message content was similar to the posts used in social media.

Although birdwatchers were our main target audience, our project was broadcast in mass media and anyone could apply to participate. Because the scheme of our project was the first of its kind in Brazil, we included a short questionnaire in the application form to assess the applicants' birding expertise and their willingness to visit forest patches in this type of agricultural landscape (see supplementary file). Applicants were not required to answer the questions in the questionnarie, and all ethics rules in working with human subjects were followed. Considering a variety of birding expertise among applicants, our strategy to encourage them to visit the forest patch at least once, either by themselves or with our research team, was sending messages emphasizing the benefits for science and society when there is public participation in citizen science projects like ours (Chu et al. 2012; Pettibone et al. 2016). We stated that we accepted applicants under 18 years old only if we received documented permission from their parents or legal guardian. Lastly, we did not state the exact number of banded birds in the forest patch, and the patch's location was kept private in the questionnaire in order to not influence each applicant's answers to the questions.

\section{Bird monitoring by volunteers}

When a volunteer decided to visit the patch, s/he would first tell us which day they would go so we could control the number of participants in each transect per day. Afterwards, we emailed them a map with directions to reach the Santa Olímpia patch and the three internal forest transects. Along each transect, we marked each $150 \mathrm{~m}$ section, approximately, with vivid color stripes (i.e., bright pink or bright orange) tied to trees with a sequential number (i.e., S1, S2, S3, etc., see Figure 2c) to help with data collection. We also sent instructions on how to collect the data in a standardized way. We asked volunteers to do their birding on the internal trails and take notes of their bird records (i.e., visual or auditory record). If a banded bird was seen, the volunteer would document the band colors and sequence (i.e., banding sequence was read from lowest to highest band), the species, and the trail section along which the bird was seen. These data could be collected and delivered to us using several options, including the project's app (https://play.google.com/store/ apps/details?id=com.taxeus.avepulseiras\&hl=en); taking a picture and publishing later on any online platform for sharing images (e.g., WikiAves, BioFaces, personal blogs, webpages, etc); sending the research team a photo link and the location information; taking notes in a notebook and emailing the data; and/or by sending us a picture of the field notebook used during the tour.

We did not require specific days of visit, periods (i.e., morning or afternoon), or amount of time spent in the field, but we did suggest that volunteers walk at least one whole transect per visit. Also, we suggested walking along internal transects n. 1 and n. 2, which were next to the mist-net stations.

\section{Assessing bird data viability}

To assess the viability of bird tarsi visualization in the forest, the project's field team, composed of one ornithologist with $>10$ years of expertise and three students, conducted 64 hours of birding surveys in the transects during 20 field days between November/2016 and January/2018, collecting only species lists per transect section from sunrise until noon. Our objective was to quantify the rate of tarsi visualization per bird record, which indicated how feasible it would be for birdwatching citizen scientists to collect these data.

Our birding surveys were planned to be similar to typical birding tours commonly done by birdwatchers in Brazil (e.g., Alexandrino et al. 2012). Thus, we walked the transects in an ad libitum mode (i.e., time for walking and stops were not controlled and we collected bird records as totally random events). We used $8 \times 42$ binoculars and professional or semi-professional cameras with 80-300 mm lens or greater, wore dark green or camouflaged clothes, and avoided producing noise or conversation during the birding tour. Only the internal transects were used for this work. For each bird record (i.e., visual or auditory), we first identified the species present and then tried to locate them by following their signs. For every visual record, we took notes on whether the bird's tarsi were clearly seen, and if so, we took notes about absence or presence of the bands and their colors. 


\section{Results}

\section{Project applicants versus volunteers in the field}

Until May 3, 2018, we received 302 applicants, all of whom answered our online questionnaire. Applicants steadily increased during the 128 days of project advertisements (Figure 3a). In addition, 90\% of the applicants (275) declared that they were informed about the project through our messages in social media or that they received emails about the project (Figure $\mathbf{3 b}$ ), indicating that internet broadcasting is an efficient tool to recruit volunteers for citizen science projects (Liberatore et al. 2018; Frigerio et al. 2018).

From our 302 applicants, 262 were WikiAves users (86.7\% of our applicants), but only $32 \%$ were eBird users. In 27 February 2018, when we estimated the number of birdwatchers in Brazil in the starting period of our data analysis, WikiAves had 28,604 users. Of those, only 12,734 (44.4\%) have at least one picture or song of any bird species uploaded in their WikiAves account. Assuming that these users represent all active birdwatchers in Brazil, we were able to attract roughly $2 \%$ of Brazilian birdwatchers. We had 222 applicants from São Paulo state (73.5\% of our applicants), the state with the most number of active birdwatchers (3,851 WikiAves users, 30\% of users in Brazil). Of those, 195 applicants were users of WikiAves. Thus, our project reached approximately $5 \%$ of the suspected number of active birdwatchers in the São Paulo state.

We mostly considered applicants who were residents near the project's forest patch as potential citizen scientists to do at least one visit to the patch (see Seymour and Haklay 2017), because short day trips for birdwatching are common among birdwatchers (Tulloch and Szabo 2012; U.S. Department of the Interior et al. 2016), a tendency also observed among Brazilians (Alexandrino et al. 2018). Even though the number of applicants represented a small proportion of existing birdwatchers in São Paulo state, we still received 155 applicants who lived in cities not more than $200 \mathrm{~km}$ from our patch (Figure 3b). Of those, 152 (98\%) declared that they were familiar with birdwatching inside forested environments, 139 (89.6\%) had intermediate or high birding skill, and $73(47 \%)$ had been birdwatching for over six years (Figure $3 \mathbf{c}$ ). Thus, we had an adequate number of applicants with enough skill to collect the data required for our project. In addition, 64 applicants expressed willingness to travel at least $200 \mathrm{~km}$ to visit a forest patch in an agricultural landscape (41\% of 155 applicants, Figure 3d). Most of the applicants (64\%) also answered that other leisure amenities near the forest patch, such as waterfalls, scenic beauty, historical centers, museums, gastronomic tourism, etc., were not important factors influencing their willingness to visit a forest patch in an agricultural landscape (Figure $\mathbf{3 d}$ ).

Although we had 155 applicants with the potential to visit our patch, only 10 actually completed the survey (6.4\% of the 155 applicants and $3.3 \%$ of all 302 applicants). Three of them visited the patch once with the project's field work team, and seven visited the patch alone, with six visiting only one day, and one volunteer visiting for four days. Thus, we did not achieve our objective to have a high number of birdwatchers visiting the patch by themselves. We knew that engaging volunteers would be a difficult task (Chu et al. 2012; Seymour and Haklay 2017; McKinley et al. 2017; Frigerio et al. 2018), but after our continuous efforts to recruit and interest birdwatchers proved successful, we were expecting more citizen scientists to participate in the field work.

\section{Bird data sampling: Assessing the bird monitoring viability}

At the end of our bird banding campaigns, we had 108 banded individuals representing 24 species. Considering the small size of our study forest patch, this number was adequate for monitoring individuals in the field, especially at points close to the bird banding stations. The seven citizen scientists who visited the patch by themselves provided 86 bird records (i.e., visual or auditory) representing 53 species in 24 hours of sampling effort (i.e., 3.5 records/hour) during eight days of the project period. This effort resulted in the records of only three banded birds from two species, all of which were recorded by one expert volunteer in one field day. The other volunteers declared after their visit that seeing birds was not easy inside the forest patch, despite the fact that all of them had previously declared familiarity with birdwatching in forested environments and had claimed intermediate to high-level birding skills. Volunteer's sighting records were significantly lower than those collected during 64 hours of birding surveys done by our project's field team (KruskalWallis test, chi-square $=4.78, \mathrm{P}<0.05)$. We had 1,333 bird records representing 120 species (20 records/hour), from which 361 were bird visualizations and 237 records resulted in the tarsi clearly visualized $(65.6 \%$ of all visual bird records) representing 20 banded bird sightings from 13 individuals of eight species (Bovo 2016; Paulete 2016; Cordeiro 2017).

The overall banded bird visualizations were low both by the ornithologist team and by the birdwatching volunteers. Altogether, only 23 banded birds were observed from 15 individuals of nine species, meaning that only $13.8 \%$ of the banded individuals were observed, assuming that no color bands were lost. However, our results indicate that tarsi visualization inside the forest is not a difficult task when the field collector is trained or has a high level of birding expertise. Thus, we believe that banded records would increase if more field work was completed by citizen scientists with more expertise.

\section{Discussion}

Reasons for the lack of field volunteers: Motivations and barriers

We planned and executed our project focusing on motivations that we believed would lead Brazilian birdwatchers to participate in our project. However, as projects based on fine-scale bird monitoring by citizen scientists are nonexistent in Brazil, we faced unexpected barriers hindering volunteer engagement. We explain these factors in detail below. 


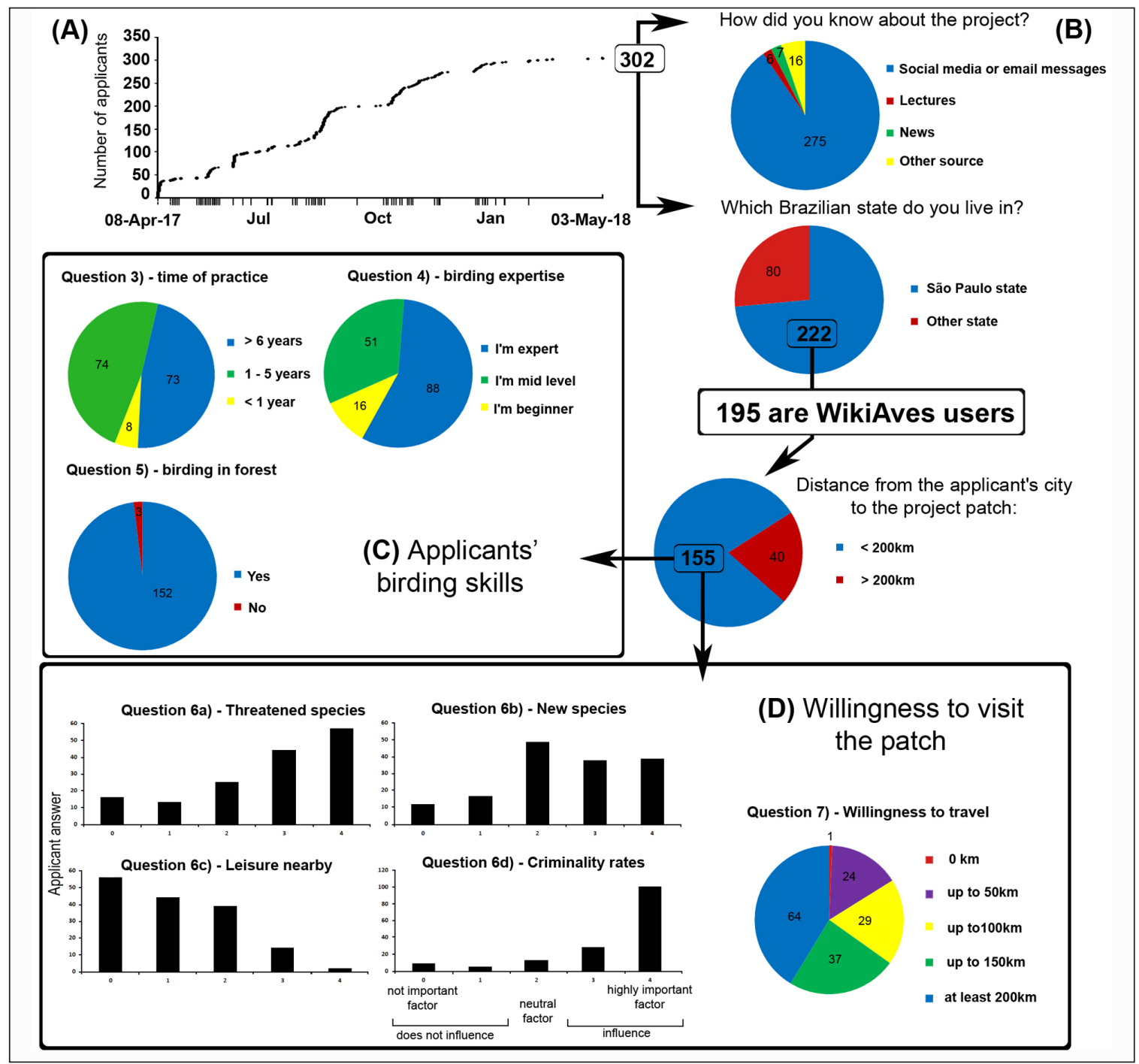

Figure 3: Results from our questionnaire. A) Accumulation of the number of new applicants in the project. Marks on the $\mathrm{x}$ axis represent a day with project advertisement, totaling 128 days. B) Answers from the 302 applicants. C) The birding skill of 155 applicants who were WikiAves users and residents of areas less than $200 \mathrm{~km}$ from the forest patch. These applicants had high potential to both visit the patch and correctly identify birds during survey. D) Willingness of the 155 applicants to visit the forest patch. In question 6, answers were on a $0-4$ scale. Answers with a 0 or 1 count mean the specific factor would not influence the applicant's willingness to visit the patch, while answers with a 3 or 4 count mean that the specific factor would influence the applicant's willingness to visit the patch. See supplementary file for the complete questions.

Motivation: Providing a challenge and friendly competition One of the many pleasures of birdwatching is the surprise factor, or the lack of control over both the events and species recorded in the field (Alexandrino et al. 2012). As we knew a priori that the number of banded birds would be relatively low, we thought that utilizing this added difficulty of finding a banded bird might entice avid birders interested in a new and unique challenge (Scott et al. 1999). Banded bird photos are rare in WikiAves and in other online birding databases like eBird, but positive comments about these records and questions about the bird's origin are common among users. Therefore, we expected that this challenge would catch the attention of expert birdwatchers interested in a unique photographic experience.
Motivation: Easy and free access and no restrictions on photography

Many birdwatchers complain that some Brazilian forest parks do not allow public entrance early in the morning, when the chance of seeing bird species is highest. Also, in many public parks and reserves of São Paulo state, a birdwatcher interested in taking photographs of birds must first apply for a license from park managers and accept an accordance that those pictures will not be used for commercial purposes (e.g., see Fundação Florestal 2016, which regulates birdwatching and photography practices in parks throughout São Paulo state). Although getting the license, in general, is not a complicated task, this commitment is considered a breach of freedom for many bird-photography enthusiasts, causing displeasure among birdwatchers. Therefore, we emphasized in our 
advertisements that there were no impediments to professional photography and no rules against what time of day a citizen scientist can participate in a project survey.

\section{Motivation: Altruistic behavior and helping environmental science}

Many birdwatchers feel proud when their bird records are used in scientific studies (Scott et al. 1999; Cohn 2008; Chu et al. 2012; Sullivan et al. 2014), and this altruistic behavior and self-gratification may contribute to feelings of well-being (e.g., Morrow-Howell et al. 2003). Thus, we believed that our project advertisements, which used catchy images and short videos of banded birds being released along with short explanations of our project intentions, would be enough to attract volunteers for our project (Chu et al. 2012). However, we concluded that our outreach, combined with the other motivations mentioned above, was not sufficient due to certain barriers.

\section{Barrier: No choice of location}

In citizen science projects that have high volunteer engagement, volunteers are commonly given the choice to collect data in places where they are not expected to go too far out of their way (Tulloch and Szabo 2012; Klemann-Junior et al. 2017). This not only gives volunteers the ability to choose locations that fit best with their daily lives (Seymour and Haklay 2017); it also gives citizen scientists a sense of ownership over the project (Chu et al. 2012; Austin Green, unpublished data). With the eventual exclusion of patch A and B from our project's study area, we unintentionally restricted prospective citizen scientists to a single geographic area with little to no freedom of choice. Thus, as the Santa Olimpia patch satisfied only a fraction of our applicants, we immediately limited our potential target audience to residents of certain geographical locations, eliminating many citizen scientists from our prospective pool.

\section{Barrier: Lack of new or rare species for the birdwatcher's} list

The bird species in our forest patch were mostly common species that also could be observed in many other patches in the São Paulo state countryside (Hasui et al. 2018), and only a few Atlantic Forest endemics and near threatened species were recorded in our patch. Many birdwatchers are selective when it comes to birding (Tulloch and Szabo 2012), travelling to birdwatching areas simply for the chance to see a species not previously recorded on their personal life list. In addition, many birders strive to observe threatened species, which are more difficult to observe than common species, given their low population densities and limited distributions. Furthermore, WikiAves assigns a rating of difficulty to each species based on its rate of occurrence. Both threatened and endemic species are among the most difficult to spot and thus receive the highest ratings (WikiAves 2018). Only $18.7 \%$ of the 155 applicants answered that new species for their bird life list was not a factor that would influence their willingness to visit a forest patch, while $31.6 \%$ showed indifference to this factor and $49 \%$ answered that it was an important factor in their willingness to participate (Figure 3d). Likewise, 65\% of applicants indicated that threatened species occurrence was an important factor in their willingness to participate and visit a forest patch for this study (Figure 3d). Thus, we believe that the lack of rare and endemic species in our forest patch contributed to the lack of birdwatchers in the bird data collection.

Barrier: Lack of immediate feedback and support for citizen scientists

Returning clear information about the data provided by each citizen scientist in a short period of time is essential to any successful citizen science project, and it is also a useful way to engage volunteers (Chu et al. 2012; Pettibone et al. 2016; McKinley et al. 2017; Sullivan et al. 2017). Because we had limited funds and personnel, our project did not have the ability to create a proper channel of communication between our research team and individual citizen scientists, nor did we have the immediate ability to answer questions from citizen scientists as they inevitably came up. Our mobile app was limited to bird record uploads only, and no information about the individual bird could be instantly accessed, such as how distant the banded bird recorded was from the location where that bird was captured and marked. Such feedback could be a positive factor toward the volunteer's satisfaction and could help encourage other applicants to participate.

Barrier: Lack of security nearby the patch

Although our field team did not have any security problems while conducting fieldwork in the study area, there were cases of robbery nearby, and this is a common problem in the rural Sao Paulo countryside (Ceccato and Ceccato 2017). Many birdwatchers use expensive optical equipment (i.e., binoculars, scopes, cameras) to help with their bird identification records (Pivatto et al. 2007; U.S. Department of the Interior et al. 2016). Therefore, we believe that after the applicants were informed about the forest patch location, which was provided only after completion of the application process, many of them decided not to visit the patch, as avoiding areas with low security is a common behavior among Brazilian birdwatchers (Pivatto et al. 2007, see Figure 3d).

\section{Bird data collected: Consequences for forest restoration investigation}

Low numbers of banded bird records were expected due to the low ecological integrity of forest patches in the study area (Alexandrino et al. 2017), where food supply may not be sufficient to support resident birds (Verga et al. 2017), forcing them to explore adjacent patches in other landscapes to feed (Pizo and Santos 2011; Luz 2013; Boesing et al. 2017). We believe that many banded birds were moving through the landscape, using patches as stepping stones in regional movement (Marini 2010; Prevedello et al. 2018). This behavior may suggest large home range sizes for forest birds in this agricultural landscape (Şekercioğlu 
et al. 2007; Marini 2010; Silveira et al. 2016; Prevedello et al. 2018). Therefore, the lack of banded bird records in our target patch is indeed an important clue for our passive restoration investigation, suggesting that many fruit consumers could spread plant seeds beyond the forest edges.

Professionals joining forces with citizen scientists for long-term bird monitoring in this region is still a promising partnership (e.g., Şekercioğlu 2012). We again emphasize that there is little knowledge about bird movement through forest patches and within an agricultural matrix in the Neotropics (e.g., Marini 2010; Silveira et al. 2016; Giubbina et al. 2018). Thus, data gathered over a larger extent of the agricultural matrix and in other forest patches nearby our target patch, which could be possible only through incorporation of community citizen scientists, could provide both complementary and baseline data on bird movement, supplementing our current project investigating restoration ecology efforts in the region.

\section{Unexpected results of the project: New opportunities for future ornithological citizen science in Brazil}

As our project was highly broadcast through both television and social media outlets, we received a great deal of unexpected messages from citizens in Brazil interested in both reporting records of banded birds as well as participating in our project, even though they were more than 200 km from our study site (Mendes 2017; Santos 2017; Azevedo 2018). Although the records that they wished to report most likely were not from our study area (as we are currently aware of other ornithologists conducting bird banding campaigns in a variety of habitats and localities throughout Brazil), their reports revealed that news about our project reached far beyond our target audience, sparking interest in citizens all across Brazil. Therefore, as the number of birdwatchers in Brazil continues to increase, we believe that the implementation of an integrated monitoring program for color-banded birds via citizen science could be promising. Some local efforts are currently being managed in other parts of the world (e.g., http://www.cr-birding.org; https://www.ringmerking.no/cr/).

The Centre for Bird Monitoring from the Brazilian Institute for Environmental Affairs (CEMAVE/IBAMA) is responsible for the control of numbered metallic ring distribution and for maintenance of the national ringed bird data. However, there is no coordination between projects using color bands for identification, with each project operating independently of all others. If coordination could be achieved between these projects, individual bird monitoring could be implemented based on citizen science records, allowing data to be shared across several research initiatives in ornithology and ecology, such as home range investigation, bird life longevity, migration routes, permeability of the agricultural matrix, and land use (Anderson and Green 2009).

When we realized this potential, we began inviting other Brazilian ornithologists to become partners by contacting researchers that are doing banding campaigns in
São Paulo city and in the central area of Minas Gerais state, near Itaverava city. We told them that if they were willing to include their study area in the project's app, we would broadcast the information that new areas with banded birds were available to birdwatchers. Unfortunately, the research groups that we contacted did not agree to this partnership, indicating that better coordination and communication between ornithologists is needed. Regardless, we will continue to spread this idea throughout Brazil to urge ornithologists to understand the potential of such programs.

\section{Final Comments}

Although we reached a large and potentially suitable audience, we recognize that the motivations to engage birdwatchers were not enough to overcome the possible personal and social barriers involved in our particular study. However, we emphasize that birdwatcher engagement can help researchers conduct fine-scale monitoring, and we believe the future is promising, as the number of Brazilian birdwatchers is continuing to increase. We hope that our findings may guide other researchers in planning similar citizen science-based projects in Brazil and in other countries.

\section{Supplementary File}

The supplementary file for this article can be found as follows:

- Supplementary file $\mathbf{1}$. Short questionnaire used in the application form. DOI: https://doi.org/10.5334/ cstp.198.s 1

\section{Acknowledgements}

We thank all applicants and volunteers that believe in the potential of our project. We also thank other colleagues and students who helped us in some field campaigns: Alex A. A. Bovo, Renan A. Bonança, Livia Barreto, Isabela Correa, Mariana Pariz, Juan Domini, Liliane Trevisan, Thaina C. Muniscelli, Bruna Pacheco, Beatriz Lopes, Sélim Ben Chéhida, Kissyla Tonon, Letícia Munhoz, Marcia Sousa, and Bruna Tamasauskas. We thank Silvio Marchini for rich commentaries of our research. This project was approved by Intuitional Animal Care and Use Committee of ESALQ/USP, project register n. 2016-14 and Brazilian Center for Bird Conservation - CEMAVE, project register n. 4141. Eduardo R. Alexandrino has CEMAVE registration as senior ringer number 3695854; Brazilian Biodiversity Authorization and Information System - SISBIO, project register n. 5503. This work is approved by the Ethics Committee on Research with Human Beings from the Escola Superior de Agricultura "Luiz de Queiroz," University of Sao Paulo" (ESALQ/USP), protocol number: 1.977.454, and also has a Certificate of Presentation for Ethical Appreciation number: 63717316.5.0000.5395. This research was part of a project "Forest patches with passive restoration in agricultural landscapes: Birds as ecological assessment tool and promoters of ecosystem services." 
This study was financed in part by the Coordenação de Aperfeiçoamento de Pessoal de Nível Superior - Brasil (CAPES) - Finance Code 001. Eduardo R. Alexandrino is a post-doctoral researcher supported by CAPES PNPD 2013/1723. Ana B. Navarro is supported by CAPES PROEX of PPGI-EA. Katia M.P.M.B. Ferraz is funded by Conselho Nacional de Pesquisa e Desenvolvimento Científico e Tecnológico (CNPq/Brazil) research grant (process 308503/2014-7).

\section{Competing Interests}

The authors have no competing interests to declare.

\section{Author Contributions}

The research idea (i.e., contextualization, objectives, planning the steps of the Citizen Science project), the experimental design, the field bird survey, data analysis, and paper writing were done by E. R. Alexandrino under supervision of K.M.P.M.B. Ferraz., H.T.Z Couto, and C. H. Sekercioglu; A.Green and C. H. Sekercioglu helped in the writing process, mainly in the discussion of our results and the English review of the final manuscript; A.B. Navarro, V.F. Paulete, M.Camolesi, and V.G.R. Lima helped in the experimental design and the development of the CS project, and they were part of the permanent field ornithologist team; T. Conto did the data mining from WikiAves website and helped in the writing process; K.M.P.M.B. Ferraz and H. T.Z Couto also provided substantial contributions with materials and logistics.

\section{References}

Abolafya, M, Onmuş, O, Şekercioğlu, ÇH and Bilgin, R. 2013. Using citizen science data to model the distributions of common songbirds of Turkey under different global climatic change scenarios. PLoS One, 8: e68037. DOI: https://doi.org/10.1371/journal. pone.0068037

Aleixo, A. 1999. Effects of selective logging on a bird community in the Brazilian Atlantic forest. The Condor, 101: 537-548. DOI: https://doi.org/10.2307/1370183

Alexandrino, ER, Buechley, ER, Karr, JR, Ferraz, KMPMB, Ferraz, SFB, Couto, HTZ and Sekercioglu, CH. 2017. Bird based Index of Biotic Integrity: Assessing the ecological condition of Atlantic Forest patches in human-modified landscape. Ecological Indicators, 73: 662-675. DOI: https://doi.org/10.1016/j. ecolind.2016.10.023

Alexandrino, ER, Buechley, ER, Piratelli, AJ, Ferraz, KMPMB, Moral, RA, Sekercioglu, CH, Silva, WR and Couto, HTZ. 2016. Bird sensitivity to disturbance as an indicator of forest patch conditions: An issue in environmental assessments. Ecological Indicators, 66: 369-381. DOI: https://doi.org/10.1016/j. ecolind.2016.02.006

Alexandrino, ER, Mendes, RLS, Ferraz, KMPMB and Couto, HTZ. 2018. Regiões paulistas carentes de registros ornitológicos feitos por cidadãos cientistas. Atualidades Ornitológicas, 201: 33-39.

Alexandrino, ER, Queiroz, OTMM and Massarutto, RC. 2012. O potencial do município de Piracicaba (SP) para o turismo de observação de aves (Birdwatching). Revista Brasileira de Ecoturismo, 5(1): 27-52.

Anderson, GQ and Green, RE. 2009. The value of ringing for bird conservation. Ringing \& Migration, 24(3): 205-212. DOI: https://doi.org/10.1080/03078698.20 09.9674393

Angelo, C. 2017. Brazilian scientists reeling as federal funds slashed by nearly half. Nature News \& Comment. DOI: https://doi.org/10.1038/nature.2017.21766

Azevedo, CJ. 2018. Photograph record WA3005649. Caracara plancus (Miller, 1777). Available in: http://www. wikiaves.com/3005649. Accessed in 15 Sept 2018.

Banks-Leite, C, Pardini, R, Tambosi, LR, Pearse, WD, Bueno, AA, Bruscagin, RT, Condez, TH, Dixo, M, Igari, AT, Martensen, AC and Metzger, JP. 2014. Using ecological thresholds to evaluate the costs and benefits of set-asides in a biodiversity hotspot. Science, 345: 1041-1045. DOI: https://doi.org/10.1126/science. 1255768

Bello, C, Galetti, M, Pizo, MA, Magnago, LFS, Rocha, MF, Lima, RAF, Peres, CA, Ovaskainen, $\mathbf{O}$ and Jordano, P. 2015. Defaunation affects carbon storage in tropical forests. Science Advances, 1(11): e1501105. DOI: https://doi.org/10.1126/sciadv.1501105

Birding News. 2017. "Eu vi uma ave usando pulseiras?!" - A observação de aves a serviço da ciência. Online access at: http://www.birdingnews.com.br/joomla/ menu-fauna-brasil/cat-noticias/aves-de-pulseiranovo. Last accessed in $11 \mathrm{Jul} 2018$.

Boesing, AL, Nichols, E and Metzger, JP. 2017. Land use type, forest cover and forest edges modulate avian cross-habitat spillover. Journal of Applied Ecology. DOI: https://doi.org/10.1111/1365-2664.13032

Bovo, AA. 2016. Photograph record WA2522665, Manacus manacus (Linnaeus, 1766). Available in: http://www. wikiaves.com/2522665. Accessed in $05 \mathrm{Jul} 2018$.

Bovo, AA, Ferraz, KMPMB, Magioli, M, Alexandrino, ER, Hasui, É, Ribeiro, MC and Tobias, JA. 2018. Habitat fragmentation narrows the distribution of avian functional traits associated with seed dispersal in tropical forest. Perspectives in ecology and conservation, 16(2): 90-96. DOI: https://doi.org/10.1016/j. pecon.2018.03.004

Brancalion, PH, Bello, C, Chazdon, RL, Galetti, M, Jordano, P, Lima, RAF, Medina, A, Pizo, MA and Reid, JL. 2018. Maximizing biodiversity conservation and carbon stocking in restored tropical forests. Conservation Letters, e12454. DOI: https://doi. org/10.1111/conl.12454

Brancalion, PHS, Viani, RAG, Strassburg, BBN and Rodrigues, RR. 2012. Finding the money for tropical forest restoration. Unasylva, 63(1): 25-34.

Callaghan, CT, Martin, JM, Major, RE and Kingsford, RT. 2018. Avian monitoring - comparing structured and unstructured citizen science. Wildlife Research, 45: 176-184. DOI: https://doi.org/10.1071/WR17141

Cassiano, CC, Ferraz, SFB, Molin, PG, Voigtlaender, M and Ferraz, KMPMB. 2013. Spatial assessment of water-related ecosystem services to prioritize restoration of forest patches. Natureza \& Conservação, 
11(2): 176-180. DOI: https://doi.org/10.4322/natcon.2013.027

Ceccato, V and Ceccato, H. 2017. Violence in the Rural Global South: Trends, Patterns, and Tales From the Brazilian Countryside. Criminal Justice Review, 42(3): 270-290. DOI: https://doi. org/10.1177/0734016817724504

César, RG, Moreno, VS, Coletta, GD, Chazdon, RL, Ferraz, SFB, Almeida, DRA and Brancalion, PHS. 2018. Early ecological outcomes of natural regeneration and tree plantations for restoring agricultural landscapes. Ecological Applications, 28(2): 373-384. DOI: https://doi.org/10.1002/eap.1653

Chandler, M, See, L, Copas, K, Bonde, AM, López, BC, Danielsen, F, Legind, JK, Masinde, S, Miller-Rushing, AJ, Newman, G, Rosemartin, A and Turak, E. 2017. Contribution of citizen science towards international biodiversity monitoring. Biological Conservation, 213: 280-294. DOI: https://doi.org/10.1016/j.biocon.2016.09.004

Chu, M, Loenard, P and Stevenson, F. 2012. Growing the base for citizen science: Recruiting and engaging participants. In: Dickinson, JL and Bonney, $\mathrm{R}$ (eds.), Citizen Science: Participation in Environmental Research, 88-96. Ithaca and London: Comstock Publishing Associates. DOI: https://doi.org/10.7591/ cornell/9780801449116.003.0005

Cohn, JP. 2008. Citizen science: Can volunteers do real research? BioScience, 58(3): 192-197. DOI: https://doi. org/10.1641/B580303

Cordeiro, TM. 2017. Photograph record WA2744737, Manacus manacus (Linnaeus, 1766). Available in: http://www.wikiaves.com/2744737. Accessed in 05 Jul 2018.

Cordell, HK and Herbert, NG. 2002. The popularity of birding is still growing. Birding, 34(1): 54-61.

Cullen, L, Jr., Bodmer, ER and Valladares-Padua, C. 2001. Ecological consequences of hunting in Atlantic forest patches, São Paulo, Brazil. Oryx, 35(2): 137-144. DOI: https://doi.org/10.1046/j.13653008.2001.00163.x

Dean, W. 1997. A ferro e fogo: A história e a devastação da Mata Atlântica brasileira, 484. São Paulo: Companhia das Letras.

Dias, DF, Ribeiro, MC, Felber, YT, Cintra, AL, Souza, NS and Hasui, É. 2016. Beauty before age: Landscape factors influence bird functional diversity in naturally regenerating fragments, but regeneration age does not. Restoration Ecology, 24(2): 259-270. DOI: https:// doi.org/10.1111/rec.12293

Eler, G. 2018. O que é ciência cidadã. E como ela contribui para a preservação de espécies. Nexo Jornal. 21 January. Online access at: www.nexojornal.com. br/expresso/2018/01/21/O-que-é-ciência-cidadã.E-como-ela-contribui-para-a-preservação-de-espécies Last accessed in $11 \mathrm{Jul} 2018$.

Ferraz, KMPMB, Siqueira, MF, Alexandrino, ER, Luz, DTA and Couto, HTZ. 2012. Environmental suitability of a highly fragmented and heterogeneous landscape for forest bird species in southeastern
Brazil. Environmental Conservation, 39: 316-324. DOI: https://doi.org/10.1017/S0376892912000094

Ferraz, SFB, Ferraz, KMPMB, Cassiano, CC, Brancalion, PH, Luz, DTA, Azevedo, TN, Tambosi, L and Metzger, JP. 2014. How good are tropical forest patches for ecosystem services provisioning? Landscape Ecology, 29(2): 187-200. DOI: https://doi.org/10.1007/ s10980-014-9988-z

Frigerio, D, Pipek, P, Kimmig, S, Winter, S, Melzheimer, J, Diblíková, L, Wachter, B and Richter, A. 2018. Citizen science and wildlife biology: Synergies and challenges. Ethology, 124(6): 365-377. DOI: https://doi.org/10.1111/eth.12746

Fundação Florestal. 2016. Portaria Normativa FF DE 236/2016 - Dispõe sobre procedimentos para realização da atividade de Observação de Aves nas Unidades de Conservação administradas pela Fundação Florestal (in portuguese). Available in: http://fflorestal.sp.gov.br/portaria-normativa-ff-de-no-2362016. Accessed in 10 Jul 2018.

G1. 2017. Terra da Gente. Available in: http://g1.globo. com/sp/campinas-regiao/terra-da-gente/videos/t/ edicoes/v/descendentes-de-italianos-reflorestambairro-rural-em-piracicaba-bloco-02/5751588/. Last accessed in 11 Jul 2018.

Giubbina, MF, Martensen, AC and Ribeiro, MC. 2018. Sugarcane and Eucalyptus plantation equally limit the movement of two forest-dependent understory bird species. Austral Ecology, 43(5): 527-533. DOI: https:// doi.org/10.1111/aec.12589

Hallworth, MT and Marra, PP. 2015. Miniaturized GPS Tags Identify Nonbreeding Territories of a Small Breeding Migratory Songbird. Scientific Reports, 5: 11069. DOI: https://doi.org/10.1038/srep11069

Hasui, É, Metzger, JP, Pimentel, RG, Silveira, LF, Bovo, AAA, Martensen, AC, Uezu, A, Regolin, AL, Oliveira, AAB, Gatto, CAFR, Duca, C, Andretti, CB, Banks-Leite, C, Luz, D, Mariz, D, Alexandrino, ER, Barros, FM, Martello, F, Pereira, IMS, Silva, JN, Ferraz, KMPMB, Naka, LN, Anjos, L, Efe, MA, Pizo, MA, Pichorim, M, Gonçalves, MSS, Cordeiro, PHC, Dias, RA, Muylaert, RL, Rodrigues, RC, Costa, TVV, Cavarzere, V, Tonetti, VR, Silva, WR, Jenkins, CN, Galetti, M and Ribeiro, MC. 2018. ATLANTIC BIRDS: A data set of bird species from the Brazilian Atlantic Forest. Ecology, 99(2): 497. DOI: https://doi. org/10.1002/ecy.2119

Horns, JJ, Adler, FR and Şekercioğlu, ÇH. 2018. Using opportunistic citizen science data to estimate avian population trends. Biological Conservation, 221: 151-159. DOI: https://doi.org/10.1016/j.biocon.2018.02.027

Klemann-Junior, L, Vallejos, MAV, Scherer-Neto, P and Vitule, JRS. 2017. Traditional scientific data vs. uncoordinated citizen science effort: A review of the current status and comparison of data on avifauna in Southern Brazil. PloS one, 12(12): e0188819. DOI: https://doi. org/10.1371/journal.pone.0188819

Liberatore, A, Bowkett, E, MacLeod, CJ, Spurr, E and Longnecker, N. 2018. Social Media as a Plat- 
form for a Citizen Science Community of Practice. Citizen Science: Theory and Practice, 3(1): 3, 1-14. DOI: https://doi.org/10.5334/cstp.108

Luz, DTA. 2013. Ecologia trófica em matrizes agrícolas: Uso da ferramenta isotópica para conservação de aves em ambientes antrópicos. Unpublished dissertation, Universidade de São Paulo.

Majer, JD. 2009. Animals in the restoration process - progressing the trends. Restoration Ecology, 17(3): 315-319. DOI: https://doi.org/10.1111/j.1526100X.2009.00528.x

Marini, MA. 2010. Bird movement in a fragmented Atlantic Forest landscape. Studies on Neotropical Fauna and Environment, 45(1): 1-10. DOI: https://doi. org/10.1080/01650521003656606

Martinelli, LA and Filoso, S. 2008. Expansion of sugarcane ethanol production in Brazil: Environmental and social challenges. Ecological Applications, 18(4): 885-898. DOI: https://doi.org/10.1890/07-1813.1

McKinley, DC, Miller-Rushing, AJ, Ballard, HL, Bonney, R, Brown, H, Cook-Patton, SC, Evans, DM, French, RA, Parrish, JL, Phillips, TB, Ryan, SF, Shanley, LA, Shirk, JL, Stepenuck, KF, Weltzin, JF, Wiggins, A, Boyle, OD, Briggs, RD, Chapin III, SF, Hewitt, DA, Preuss, PW and Soukup, MA. 2017. Citizen science can improve conservation science, natural resource management, and environmental protection. Biological Conservation, 208: 15-28. DOI: https://doi. org/10.1016/j.biocon.2016.05.015

Mendes, RL. 2017. Photograph record WA2486142, Sporophila nigricollis (Vieillot, 1823). Available in: http://www.wikiaves.com/2486142. Accessed in 05 Jul 2018.

Morrow-Howell, N, Hinterlong, J, Rozario, PA and Tang, F. 2003. Effects of volunteering on the wellbeing of older adults. The Journals of Gerontology Series B: Psychological Sciences and Social Sciences, 58(3): S137-S145. DOI: https://doi.org/10.1093/ geronb/58.3.S137

Overbeck, GE, Bergallo, HG, Grelle, CE, Akama, A, Bravo, F, Colli, GR, Magnusson, WE, Tomas, WM and Fernandes, GW. 2018. Global Biodiversity Threatened by Science Budget Cuts in Brazil. BioScience, 68(1): 11-12. DOI: https://doi.org/10.1093/biosci/ bix130

Paulete, VF. 2016. Photograph record WA2520278, Manacus manacus (Linnaeus, 1766). Available in: http://www.wikiaves.com/2520278. Accessed in 05 Jul 2018.

Peña-Domene, MDL, Martínez-Garza, C and Howe, HF. 2013. Early recruitment dynamics in tropical restoration. Ecological applications, 23(5): 1124-1134. DOI: https://doi.org/10.1890/12-1728.1

Pereira, JAA, Oliveira-Filho, AT, Eisenlohr, PV, Miranda, PLS and Filho, JPL. 2015. Human impacts affect tree community features of 20 forest fragments of a vanishing neotropical hotspot. Environmental Management, 55: 296-307. DOI: https://doi. org/10.1007/s00267-014-0387-7
Pettibone, L, Vohland, K, Bonn, A, Richter, A, Bauhus, W, Behrisch, B, Borcherding, R, Brandt, M, Bry, F, Dörler, D, Elbertse, I, Glöckler, F, Göbel, C, Hecker, S, Heigl, F, Herdick, M, Kiefer, S, Kluttig, T, Kühn, E, Kühn, K, Oswald, K, Röller, O, Schefels, C, Schierenberg, A, Scholz, W, Schumann, A, Sieber, A, Smolarski, R, Tochtermann, K, Wende, W and Ziegler, D. 2016. Citizen science for all - a guide for citizen science practitioners. Bürger Schaffen Wissen (GEWISS) publication. German Centre for integrative Biodiversity Research (iDiv) Halle-Jena-Leipzig, Helmholtz Centre for Environmental Research (UFZ), Leipzig; Berlin-Brandenburg Institute of Advanced Biodiversity Research (BBIB), Museum für Naturkunde (MfN) - Leibniz Institute for Evolution and Biodiversity Science, Berlin. 60.

Pivatto, MAC and Sabino, J. 2007. O turismo de observação de aves no Brasil: Breve revisão bibliográfica e novas perspectivas. Atualidades Ornitológicas, 139: 10-11.

Pivatto, MAC, Sabino, J, Favero, $\mathbf{S}$ and Michels, IL. 2007. Perfil e viabilidade do turismo de observação de aves no Pantanal Sul e Planalto da Bodoquena (Mato Grosso do Sul) segundo interesse dos visitantes. Revista Brasileira de Ornitologia, 15(4): 520-529.

Pizo, MA. 2007. Frugivory by birds in degraded areas of Brazil. In: Dennis, AJ, Schupp, EW, Green, RJ and Westcott, DW (eds.), Seed dispersal: Theory and its application in changing world, 615-627. Wallingford: CABI Publishing. DOI: https://doi. org/10.1079/9781845931650.0615

Pizo, MA and Santos, BTP. 2011. Frugivory, post-feeding flights of frugivorous birds and the movement of seeds in a Brazilian fragmented landscape. Biotropica, 43(3): 335-342. DOI: https://doi.org/10.1111/j.17447429.2010.00695.x

Prevedello, JA, Almeida-Gomes, $\mathbf{M}$ and Lindenmayer, DB. 2018. The importance of scattered trees for biodiversity conservation: A global meta-analysis. Journal of Applied Ecology, 55: 205-214. DOI: https:// doi.org/10.1111/1365-2664.12943

Rezende, CL, Uezu, A, Scarano, FR and Araujo, DSD. 2015. Atlantic Forest spontaneous regeneration at landscape scale. Biodiversity and conservation, 24(9): 2255-2272. DOI: https://doi.org/10.1007/s10531015-0980-y

Ribeiro, MC, Metzger, JP, Martensen, AC, Ponzoni, FJ and Hirota, MM. 2009. The Brazilian Atlantic Forest: How much is left, and how is the remaining forest distributed? Implications for conservation. Biological Conservation, 142(6): 1141-1153. DOI: https://doi. org/10.1016/j.biocon.2009.02.021

Rodrigues, RR, Lima, RA, Gandolfi, S and Nave, AG. 2009. On the restoration of high diversity forests: 30 years of experience in the Brazilian Atlantic Forest. Biological Conservation, 142(6): 1242-1251. DOI: https://doi.org/10.1016/j.biocon.2008.12.008

Santos, MM. 2017. Photograph record WA2687507, Basileuterus culicivorus (Deppe, 1830). Available in: 
http://www.wikiaves.com/2687507. Accessed in 12 Jul 2018.

Scott, D, Baker, SM and Kim, C. 1999. Motivations and commitments among participants in the Great Texas Birding Classic. Human Dimensions of Wildlife, 4(1): 50-67. DOI: https://doi. org/10.1080/10871209909359144

Şekercioğlu, CH, Loarie, SR, Brenes, OF, Ehrlich, PR and Daily, GC. 2007. Persistence of forest birds in the Costa Rican agricultural countryside. Conservation Biology, 21(2): 482-494. DOI: https://doi.org/10.1111/j.15231739.2007.00655.x

Şekercioğlu, ÇH, Wenny, DG and Whelan, CJ. (eds.) 2016. Why Birds Matter: Avian Ecological Function and Ecosystem Services. Chicago: University of Chicago Press. DOI: https://doi.org/10.7208/chicago/9780226382777.001.0001

Seymour, V and Haklay, M. 2017. Exploring engagement characteristics and behaviours of environmental volunteers. Citizen Science: Theory and Practice, 2(1): 5, 1-13. DOI: https://doi.org/10.5334/cstp.66

Sibbr. 2018. Available in: http://sibbr.gov.br/cienciacidada/. Last accessed in 05 Jul 2018.

Silveira, NS, Niebuhr, BBS, Muylaert, RL, Ribeiro, MC and Pizo, MA. 2016. Effects of land cover on the movement of frugivorous birds in a heterogeneous landscape. PLOS ONE, 11(6): e0156688. DOI: https:// doi.org/10.1371/journal.pone.0156688

Sullivan, BL, Aycrigg, JL, Barry, JH, Bonney, RE, Bruns, N, Cooper, CB, Damoulas, T, Dhondt, AA, Dietterich, T, Farnsworth, A, Fink, D, Fitzpatrick, JW, Fredericks, T, Gerbracht, J, Gomes, C, Hochachka, WM, Iliff, MJ, Lagoze, C, La Sorte, FA, Merrifield, M, Morris, W, Phillips, TB, Reynolds, M, Rodewald, AD, Rosenberg, KV, Trautmann, NM, Wiggins, A, Winkler, DW, Wong, WK, Wood, CL, Yu, J and Kelling, S. 2014. The eBird enterprise: An integrated approach to development and application of citizen science. Biological Conservation, 169: 31-40. DOI: https://doi.org/10.1016/j.biocon.2013.11.003

Sullivan, BL, Phillips, T, Dayer, AA, Wood, CL, Farnsworth, A, Iliff, MJ, Davies, IJ, Wiggins, A, Fink, D, Hochachka, WM, Rodewald, AD, Rosenberg, KV, Bonney, R and Kelling, S. 2017. Using open access observational data for conservation action: A case study for birds. Biological Conservation, 208: 5-14. DOI: https://doi.org/10.1016/j.biocon.2016.04.031

Szabo, JK, Fuller, RA and Possingham, HP. 2012. A comparison of estimates of relative abundance from a weakly structured mass-participation bird atlas survey and a robustly designed monitoring scheme.
Ibis, 154(3): 468-479. DOI: https://doi.org/10.1111/ j.1474-919X.2012.01229.X

Tambosi, LR, Martensen, AC, Ribeiro, MC and Metzger, JP. 2014. A framework to optimize biodiversity restoration efforts based on habitat amount and landscape connectivity. Restoration Ecology, 22: 169-177. DOI: https://doi.org/10.1111/rec.12049

Taxeus. 2018. Taxeus lista de espécies. Available in: https://www.taxeus.com.br/. Accessed in $11 \mathrm{Jul} 2018$.

Tulloch, AI and Szabo, JK. 2012. A behavioural ecology approach to understand volunteer surveying for citizen science datasets. Emu-Austral Ornithology, 112(4): 313-325. DOI: https://doi.org/10.1071/ MU12009

U.S. Department of the Interior, U.S. Fish and Wildlife Service and U.S. Department of Commerce, U.S. Census Bureau. 2016 National Survey of Fishing, Hunting, and Wildlife-Associated Recreation. Available: https://www2.census.gov/programs-surveys/fhwar/ publications/2016/fhw16-nat.pdf. Last accessed in 05 Jul 2018.

Valente, ROA and Vettorazzi, CA. 2003. Mapeamento de uso e cobertura do solo da Bacia do Rio Corumbataí, SP. Circular Técnica do IPEF, 196: 1-10.

Verdade, LM, Gheler-Costa, C and Lyra-Jorge, MC. 2016. The multiple facets of agricultural landscapes. In: Gheler-Costa, C, Lyra-Jorge, MC and Verdade, LM (eds.), Biodiversity in Agricultural Landscapes of Southeastern Brazil, 366. Berlin: De Gruyer. DOI: https://doi.org/10.1515/9783110480849-003

Verdade, LM, Penteado, M, Gheler-Costa, C, Dotta, G, Rosalino, LM, Pivello, VR, Piña, CI and Lyra-Jorge, MC. 2014. The conservation value of agricultural landscapes. In: Verdade, LM, Lyra-Jorge, MC and Piña, CI (eds.), Applied Ecology and Human Dimensions in Biological Conservation, 228. London, Springer. DOI: https://doi.org/10.1007/978-3-64254751-5_6

Verga, EG, Sánchez Hümöller, HL, Peluc, SI and Galetto, L. 2017. Forest fragmentation negatively affects common bird species in subtropical fragmented forests. Emu-Austral Ornithology, 117(4): 359-369. DOI: https://doi.org/10.1080/01584197.20 17.1361789

Whelan, CJ, Wenny, DG and Marquis, RJ. 2008. Ecosystem services provided by birds. Annals of the New York academy of sciences, 1134(1): 25-60. DOI: https://doi.org/10.1196/annals.1439.003

WikiAves. 2018. WikiAves - A Enciclopédia das Aves do Brasil. Available in: www.wikiaves.com.br. Accessed in 11 August 2018. 
How to cite this article: Alexandrino, ER, Navarro, AB, Paulete, VF, Camolesi, M, Lima, VGR, Green, A, de Conto, T, Ferraz, KMPMB, Şekercioğlu, ÇH and do Couto, HTZ. 2019. Challenges in Engaging Birdwatchers in Bird Monitoring in a Forest Patch: Lessons for Future Citizen Science Projects in Agricultural Landscapes. Citizen Science: Theory and Practice, 4(1): 4, pp. 1-14. DOI: https://doi. org/10.5334/cstp.198

Submitted: 16 August 2018

Accepted: 03 January 2019

Published: 15 February 2019

Copyright: $\odot 2019$ The Author(s). This is an open-access article distributed under the terms of the Creative Commons Attribution 4.0 International License (CC-BY 4.0), which permits unrestricted use, distribution, and reproduction in any medium, provided the original author and source are credited. See https://creativecommons.org/licenses/by/4.0/. ] $\mathrm{u}\left[\quad \begin{array}{l}\text { Citizen Science: Theory and Practice is a peer-reviewed open access journal published by } \\ \text { Ubiquity Press. }\end{array}\right.$ 